Summer 2011

\title{
Self-Constitutionalizing TNCs? On the Linkage of "Private" and "Public" Corporate Codes of Conduct
}

Gunther Teubner

Goeth University, Frankfurt am Main, Germany

Follow this and additional works at: https://www.repository.law.indiana.edu/ijgls

Part of the Business Organizations Law Commons, International Law Commons, and the Transnational Law Commons

\section{Recommended Citation}

Teubner, Gunther (2011) "Self-Constitutionalizing TNCs? On the Linkage of "Private" and "Public" Corporate Codes of Conduct," Indiana Journal of Global Legal Studies: Vol. 18 : Iss. 2 , Article 2. Available at: https://www.repository.law.indiana.edu/ijgls/vol18/iss2/2

This Symposium is brought to you for free and open access by the Law School Journals at Digital Repository @ Maurer Law. It has been accepted for inclusion in Indiana Journal of Global Legal Studies by an authorized editor of Digital Repository @ Maurer Law. For more information, please contact rvaughan@indiana.edu.

\section{$\Psi$}

JEROME HALL LAW LIBRARY

INDIANA UNIVERSITY

Maurer School of Law
Blooming ton 


\title{
Self-Constitutionalizing TNCs? On the Linkage of "Private" and "Public" Corporate Codes of Conduct
}

\author{
GUNTHER TEUBNER*
}

\begin{abstract}
What is special about the intertwining of private and public corporate codes? It is not only tendencies of juridification but also of constitutionalization that materialize in this interplay. Both types of corporate codes taken together represent the beginnings of specific transnational corporate constitutions conceived as constitutions in the strict sense. This point is based on a concept of constitutionalization that is not limited to the nation-state and implies that also nonstate societal orders develop autonomous constitutions under particular historical circumstances.

The following arguments highlight how corporate codes feature functions, structures, and institutions of genuine constitutions:

1. To the extent that "public" and "private" corporate codes juridify fundamental principles of a social order and establish rules for its self-restraint at the same time, they fulfill central constitutional functions.

2. With their characteristics of double reflexivity and binary metacoding, both codes develop genuine constitutional structures.

3. As constitutional institutions, the two codes do not form a hierarchy of public and private constitutions but an ultracyclical linkage of qualitatively different networks of constitutional norms.
\end{abstract}

* Goethe University, Frankfurt am Main, Germany. I would like to thank Larry Backer, Anna Beckers, and Oren Perez for helpful discussions.

Indiana Journal of Global Legal Studies Vol. 18 \#2 (Summer 2011)

(c) Indiana University Maurer School of Law 


\section{CORPORATE CODES: INCIPIENT TRANSNATIONAL CORPORATE CONSTITUTIONS?}

In recent years, transnational corporations (TNCs) were involved in a number of scandals that shocked the global public. Ecological catastrophes, like the oil spills of the Exxon Valdez in Alaska and Shell in Nigeria; inhuman labor conditions; child labor; the repression of union members; the disastrous price policy during the AIDS crisis in South Africa; the complicity of TNCs in corruption; and human rights violations drastically increased the public awareness of the negative effects brought about by the transnationalization of commercial enterprises. In parallel, these ramifications triggered a plethora of political initiatives aimed at regulating TNCs through binding legal norms. ${ }^{1}$ However, both the strong resistance of TNCs against national and supranational regulations as well as difficulties achieving effective regulation via protracted international agreements led to the failure of many of these initiatives. ${ }^{2}$ Nonetheless, one result of this shortfall is particularly noteworthy; instead of the aspired binding state regulations, a different species of transnational regimes spread in huge numbers around the globe - the "voluntary" codes of conduct of TNCs. ${ }^{3}$

Today, these codes exist in various forms, yet two basic variants predominate. On the one hand, the state world establishes-through agreements under international law or through the norms of international organizations-codes of conduct for TNCs (short and imprecise "public" codes), which prescribes for TNCs general guidelines concerning labor conditions, product quality, environmental policies, consumer protection, and human rights. Of particular significance are the United Nations Draft Code of Conduct on Transnational Corporations, the United Nations Draft Norms on Business and Human Rights, the Organization for Economic Co-operation and Development's

1. For the correlation between scandals and regulatory initiatives, see generally Walter Mattli \& Ngaire Woods, In Whose Benefit? Explaining Regulatory Change in Global Politics, in The Politics of Global Regulation 1, 22-25 (Walter Mattli \& Ngaire Woods eds., 2009).

2. For the failure of U.N. regulatory initiatives, see generally John Gerard Ruggie, Business and Human Rights: The Evolving International Agenda, 101 AM. J. INT'L L. 819 (2007).

3. For an account of the transnationalization of the corporate constitution, see generally Klaus J. Hopt, Globalisierung der Corporate Governance, in WIRTSCHAFTSETHIK DER GLOBALISIERUNG 81 (Karl Hohmann et al. eds., 2005). For the development in Germany, see generally Klaus Hopt, Corporate Governance in Germany - Recent Developments in German Company Law and the Corporate Governance Code, in FESTSCHRIFT FÜR APOSTOLOS GEORGLADES ZUM 70. GEBURTSTAG 657 (Michael Stathopoulos et al. eds., 2006). 
(OECD) Guidelines for Multinational Enterprises, and the International Labour Organization's (ILO) Tripartite Declaration of Principles Concerning Multinational Enterprises and Social Policy. ${ }^{4}$ On the other hand, the heavy public criticism globally disseminated by the media and the aggressive actions of protest movements and civil society, nongovernmental organizations (NGOs) force numerous TNCs to develop corporate codes "voluntarily." They commit themselves, effectively in public relations terms, to standards in the abovementioned issue areas and promise their implementation (again, through short and imprecise "private" codes). 5

There is still ambivalence when it comes to assessing the effects of these two kinds of corporate codes. In many cases, "public" corporate codes remain mere recommendations with no effects whatsoever. Similarly, the self-commitments in "private" codes are often only strategic attempts to preempt state regulation through a nonbinding declaration of intent, or they are mere public relations strategies without any effective change of behavior. ${ }^{6}$ This was to be expected and no longer causes a disturbance. One has to note, however, that mere symbolic legislation also exists today within private ordering. ${ }^{7}$

But there are some empirical studies that deserve particular attention. These studies demonstrate that in some cases the codes brought about real change; hence, they improved labor conditions, increased environmental protection, and pushed through human rights

4. See Sean D. Murphy, Taking Multinational Corporate Codes of Conduct to the Next Level, 43 ColUM. J. TRANSNAT'L L. 389, 403-13, 433 (2005).

5. See Kenneth W. Abbott \& Duncan Snidal, Strengthening International Regulation Through Transnational New Governance: Overcoming the Orchestration Deficit, 42 VAND. J. TRANSNAT'L L. 501, 517-18 (2009).

6. See Harry Arthurs, Private Ordering and Workers' Rights in the Global Economy: Corporate Codes of Conduct as a Regime of Labour Market Regulation, in LABOUR LAW IN an ERa of Globalization: Transformative Practices and Possibilities 471, 486-87 (Joanne Conaghan et al. eds., 2002); Tim Bartley, Institutional Emergence in an Era of Globalization: The Rise of Transnational Private Regulation of Labor and Environmental Conditions, 113 AM. J. Soc. 297, 327-28 (2007); Deborah Doane, The Myth of CSR: The Problem With Assuming That Companies Can Do Well While Also Doing Good Is That Markets Really Don't Work That Way, STAN. Soc. InNOVATION REv., Fall 2005, at 23, 2428, available at http://www.ssireview.org/articles/entry/the_myth_of_csr; Birgitta Schwartz \& Karina Tilling, 'ISO-lating' Corporate Social Responsibility in the Organizational Context: A Dissenting Interpretation of ISO 26000, 16 CORP. SOC. RESP. \& ENVTL. MGMT. 289, 294-96 (2009).

7. Private ordering, much praised for its efficiency, also suffers from the regulatory trilemma. Gralf-Peter Calliess, Die Steuerungskrise - jetzt auch im Privatrecht?, in SOZIOLOGISCHE JURISPRUDENZ: FESTSCHRIFT FÜR GUNTHER TEUBNER ZUM 65. GeburtstaG 465, 475-77 (Gralf-Peter Callies et al. eds., 2009). 
standards. ${ }^{8}$ It is particularly noteworthy that these studies not only document success stories, but they also specify the social and legal conditions that must exist if the codes are to be successful. ${ }^{9}$ Permanent NGOs monitoring or binding contracts with civil societal certification bodies are likely to be among the most important conditions for success. ${ }^{10}$

What is special about the intertwining of private and public corporate codes? This article argues not only tendencies of juridification, but also of constitutionalization, materialize in this interplay. Both types of corporate codes, taken together, represent the beginnings of specific transnational corporate constitutions conceived as constitutions in the strict sense. As further outlined elsewhere, this point is based on a concept of constitutionalization that is not limited to the nation-state and implies that also nonstate societal orders develop autonomous constitutions under particular historical circumstances. ${ }^{11}$ Moreover, in the globalizing process, the center of constitutionalization shifts from the political system to different societal sectors, which produce constitutional norms in a certain distance from the political constitutions of nation-states. ${ }^{12}$

8. See Oren Perez et al., The Dynamic of Corporate Self-Regulation: ISO 14001, Environmental Commitment and Organizational Citizenship Behavior, 43 LAW \& SoC'Y REV. 593, 622-23 (2009). See generally RESPONSIBLE BUSINESS: SELF-GOVERNANCE AND LAW IN TRANSNATIONAL ECONOMIC TRANSACTIONS (Olaf Dilling et al. eds., 2008); MARTIN HERBERG, GLOBALISIERUNG UND PRIVATE SELBSTREgULIERUNG: UMWELTSCHUTZ IN MULTINATIONALEN UNTERNEHMEN (2007).

9. Richard Locke et al., Does Monitoring Improve Labour Standards? Lessons from Nike 19, 37-38 (John F. Kennedy Sch. of Gov't, Harvard U. Corporate Soc. Responsibility Initiative, Working Paper No. 24, 2006) (indicating as conditions the size of the enterprise, the frequency of quality controls undertaken by the head office, the extension of the code to suppliers and sales, and the level of influence on national legal institutions).

10. However, this has to be qualified as well. See generally ANNEGRET FLOHR ET AL., The Role OF Business IN Global Governance: CORPORATIONS AS NORMENTREPRENEURS (2010); Michael A. Santoro, Beyond Codes of Conduct and Monitoring: An Organizational Integrity Approach to Global Labour Practices, 25 HUM. RTS. Q. 407 (2003).

11. For the concept of "societal constitutionalism" from the perspective of social theory, see generally DAVId ScIULLI, CoRPorate POWER IN CIVIL SOCIETY: AN APPLICATION OF Societal Constitutionalism 131-206 (2001); David ScIUlli, TheORY OF Societal CONSTITUTIONALISM: Foundations of a NON-MARXIST CRITICAL THEORY 21-84 (1992); Gunther Teubner, Societal Constitutionalism: Alternatives to State-Centred Constitutional Theory?, in TRANSNATIONAL Governance AND Constitutionalism 3, 7-9 (Christian Joerges et al. eds., 2004).

12. For explanations of transnational constitutionalism, see ANDREAS FISCHERLESCANo, Globalverfassung: Die GeltungSBEgRüNDUNG DER MENSCHENRECHTE 247 77 (2005); Neil Walker, The Idea of Constitutional Pluralism, 65 MoD. L. REv. 317, 339-59 (2002); Christian Walter, Constitutionalizing (Inter)national Governance: Possibilities for 
This article advances the following arguments that corporate codes feature functions, structures, and institutions of genuine constitutions: (1) to the extent that "public" and "private" corporate codes juridify fundamental principles of a social order and establish rules for its selfrestraint at the same time, they fulfill central constitutional functions; (2) both codes develop genuine constitutional structures with their characteristics of double reflexivity and binary metacoding; and (3) as constitutional institutions, the two codes do not form a hierarchy of public and private constitutions but an ultracyclical linkage of qualitatively different networks of constitutional norms.

\section{Constitutional FunCtions: Constitutive AND Limitative RULES}

Corporate codes take part in two opposing waves of constitutionalization of the world markets. Advancing Karl Polanyi's ideas about the transformation of modernity, one can even argue that transnational constitutionalism is part of a "double movement." ${ }^{13}$ Also in the trajectory of corporate constitutional law, the first movement, the expansion of economization, is followed by a second movement, which reconstructs the "protective covering of cultural institutions." 14

\section{A. Constituting Corporate Autonomy}

The first movement is identified by neomaterialist critics of a "new constitutionalism" as well as by ordoliberal advocates of a world economic constitution, naturally with diametrically opposing evaluations. ${ }^{15}$ The Washington consensus of the last thirty years has pushed ahead politically with this first surge of constitutionalization of the world markets. It not only triggered political regulation, but also fundamental principles of economic constitutionalism. They aimed at providing worldwide operating corporations with unlimited latitude for action, which encompassed ending governments holding shares in corporations, combating trade protectionism, and freeing commercial enterprises from political regulations. In this vein, the International

and Limits to the Development of an International Constitutional Law, 44 GERMAN Y.B. INT'L L. 170, 191-201 (2001).

13. Karl Polany, The great Transformation: The Political and Economic ORIGINS OF OUR TIME 136 (Beacon Press 2d ed. 2001) (1944).

14. Id.

15. For the "new constitutionalism," see DAVId SCHNEIDERMan, Constitutionalizing ECONOMic Globalization: INVESTMENT RULES AND DEMOCRACY'S PROMISE 37-45 (2008). For the ordoliberal constitution of the world economy, see generally Peter Behrens, Weltwirtschaftsverfassung, 19 JAHRBUCH FÜR NEUE POLITISCHE ÖKONOMIE 5-27 (2000). 
Monetary Fund and the World Bank have developed regime constitutions whose guiding principle is to open national capital markets. The constitutions of the World Trade Organization (WTO), the European Union (EU), the North American Free Trade Agreement (NAFTA), the Mercado Común del Cono Sur (MERCOSUR), and the Asia Pacific Economic Cooperation (APEC) all aim toward the constitutional protection of the freedom of world trade and the promotion of direct investments. Above its rules of contractual law, the lex mercatoria has developed a stratum of constitutional norms, which positivize private property, contractual freedom, competition, and human rights as transnational public policy. International standardization bodies aim at unifying national standards worldwide by linking public law and private law making. An integral part of these constitutionalization tendencies is the corporate governance of multinational corporations, whose principles encompass a high degree of corporate autonomy, the capital market-orientation of company law, and the establishment of shareholder value.

This wave of "neoliberal" constitutionalization is clearly characterized by its constitutive function (i.e., its focus on providing TNCs with a high degree of autonomy). ${ }^{16}$ It is fixated on the problem that the worldwide extension of corporate activities is hampered by the segmentary differentiation of the world into nation-states. For this fact, politics and the law of the nation-states are held responsible, as their "production regimes" restrict corporate regulation to the national framework. ${ }^{17}$ To dismantle such nation-state production regimes is therefore the primary goal. The newly emerging global corporate constitutions aim at two different goals: free TNCs from nation-state regulation and establish the rule of law globally to provide legal security for their transactions. Constitutive rules of this kind serve to release the dynamic of commercial enterprises at the global level.

\section{B. Externally Enforced Self-Restraint}

In the long run, however, it is not sustainable for corporate constitutionalism to restrict itself to its constitutive function in such a one-sidedly "neoliberal" fashion. It is only a matter of time until the

16. For the new corporate constitution of global corporate governance, see Larry Catá Backer, The Autonomous Global Corporation: On the Role of Organizational Law Beyond Asset Partitioning and Legal Personality, 41 TULSA L. REV. 541, 561 (2006).

17. For different regimes of production as stable configurations of economy, politics, and law, see Peter A. Hall \& David Soskice, An Introduction to Varieties of Capitalism, in VARIETIES OF CAPITALISM: THE INSTITUTIONAL FOUNDATIONS OF COMPARATIVE AdvanTage 8, 8-33 (Peter A. Hall \& David Soskice eds., 2005). 
released energies trigger not only positive but also such negative effects that emerging social conflicts force a drastic correction. The politically enforced demise of national production regimes results in destructive dynamics, in which the functional maximization of one sector collides with other societal dynamics. ${ }^{18}$ Now, without being significantly hampered by nation-state counter programs, globalized markets and corporations put a strain on society and the environment through the "negative effects of their own differentiation, specialization and high. performance orientation." 19 In such a "dynamic imbalance" between the opposing developments of autonomization and limitation, the tipping point has been reached. Now, it is imperative to readjust constitutional policy. ${ }^{20}$ In a second wave of constitutionalization, the limitative function of constitutional norms, instead of the constitutive form, is in demand. Corporate codes partake in this second wave when they restrict corporate activities in the name of public responsibility. They try both to overcome the primacy of shareholder value in favor of a stakeholder-orientation as well as to realize self-restraint in the areas of labor, product quality, environment, and human rights. ${ }^{21}$

\section{CONSTITUTIONAL STRUCTURES: DOUBLE REFLEXIVITY AND BINARY METACODING}

Corporate codes fulfill constitutional functions in a twofold sense: they establish constitutive rules for corporate autonomy and-at present, increasingly-limitative rules meant to counter their socially harmful tendencies. However, do they also develop constitutional structures in the strict sense? This is disputed by constitutional scholars, who recognize genuine constitutional phenomena only in the nation-state and are skeptical about a transnational and, even more so,

18. For an empirically and theoretically outstanding study in these contexts, see generally WOLFGang STREECK, RE-FoRMING CAPITALISM: INSTITUTIONAL CHANGE IN THE GERMAN POLITICAL ECONOMY (2009).

19. NiKLaA LuHMaNN, Die GESELLSCHAFT DER GESELLSCHAFT 802 (1997).

20. INO AUGSBERG ET AL., DENKEN IN NETZWERKEN: ZUR RECHTS- UND GESELLSCHAFTSTHEORIE KARL-HEINZ LADEURS 82-90 (2009); Karl-Heinz Ladeur \& Lars Viellechner, Die transnationale Expansion staatlicher Grundrechte: Zur Konstitutionalisierung globaler Privatrechtsregimes, 46 ARCHIV DES VÖLKERRECHTS 42, 56-62 (2008).

21. For the restricting constitutional functions of corporate codes, see Abbott \& Snidal, supra note 5, at 545-58; Sol Picciotto, Rights, Responsibilities and Regulation of International Business, 42 ColUM. J. TRANSNAT'L L. 131, 139-43 (2003); Peer Zumbansen, Varieties of Capitalism and the Learning Firm: Corporate Governance and Labor in the Context of Contemporary Developments in EU and German Company Law 29-38 (CLPE Law Research Inst. Research Paper Series, Research Paper No. 3, 2007), available at http://papers.ssrn.com/sol3/papers.cfm?abstract_id=993910. 
a societal constitutionalism. ${ }^{22}$ What is discussed as constitutionalization in public or private orders of globality is, so they argue, only a juridification of societal areas, partly under public international law, partly under private autonomy, yet not the generation of constitutions. This point is disputed in this section. Corporate codes should be characterized as constitutions in their own right if they develop features typical of a constitution-such as double reflexivity and binary metacoding.

\section{A. Structural Coupling of Reflexive Mechanisms}

Indeed, the codes would not establish a corporate constitution if they only introduced primary rules governing corporate activities in the fields of labor, environment, and human rights. Similarly, we would only deal with mere juridification if the codes only produced conflictsolving norms in intracorporate disputes or regulative norms for the attainment of company policies. The critical threshold is reached when the codes set forth secondary rules concerning the identification, interpretation, amendment, and competences for the enactment and delegation of primary rules. ${ }^{23}$ Typically, corporate codes show a threetiered hierarchy, in which the interplay between primary and secondary rules is discernable indeed. The top level consists of the general principles of the corporate constitution, the middle level regulates enforcement and monitoring, while the lowest level includes concrete instructions for conduct. ${ }^{24}$ At the top and middle levels, a plethora of such secondary rules can be found. They come close to constitutional norms in the strict sense, since they produce as higher-ranking metanorms a sort of reflexivity of intracompany law, but secondary norms as such do not yet create a constitution.

It is only the peculiar double character of corporate codes-here referred to as the double reflexivity of legal norms and social structures-that turns secondary norms into constitutional norms. If law plays a supportive role in the self-constituting of a social order beyond its function of conduct control, dispute settlement, regulation, and frame setting, it creates constitutional law. A corporate constitution in the strict sense only emerges if a structural coupling of a particular

22. See Dieter Grimm, The Constitution in the Process of Denationalization, 12 CONSTELLATIONS 447, 452-53 (2005).

23. H.L.A. HART, THE CONCEPT OF LAW 77-96 (1961) (defining primary and secondary rules).

24. HERBERG, supra note 8, at 68-77, 404-410; Martin Herberg, Re-Embedding the Disembedded: Die Umweltstandards multinationaler Konzerne in der globalen Steuerungsarchitektur, 56 SOZIALE WELT 399 (2005). 
kind comes into being between the corporate organization and the law. ${ }^{25}$ Coupling primary rules to organizational decisions is not sufficient; rather, coupling two reflexive processes is decisive. Transnational corporate constitutions link reflexive processes in the economic organization with reflexive legal processes; in other words, they link fundamental principles of the organization with secondary legal rules. ${ }^{26}$

An autonomous, nonstate, nonpolitical, and hence genuinely societal constitutionalization occurs in the codes of TNCs, since they juridify reflexive social processes that concern the relationship of the company with its environments by linking them to their partially reflexive legal processes (i.e., standardizations of standardizations). Under this condition, it is reasonable to discuss elements of a genuine constitution within the corporate codes of TNCs. The codes indeed show typical elements of a constitution: regulations concerning the establishment and practice of organizational decision making (procedural rules of the corporation) and the definition of the system boundaries (fundamental rights of individuals and institutions vis-à-vis the corporation).

The norms at the top level of corporate codes are especially geared toward these conditions. They regulate the fundamental decisionmaking processes of TNCs, which concern the relationship with their human and natural environments, especially the relationship with the employees whose fundamental rights are respected by the organization. The "guidelines" at the top level have constitutional character, since they are not only mere behavioral norms, like the rules at the lowest level. Rather, they are explicitly higher-ranking norms, phrased as general principles and serving both as starting points for generation of intracorporate norms and as yardsticks for the internal and external review of norms. This requires certain institutional arrangements, especially procedural roles, which are responsible for setting, modifying, interpreting, and implementing the primary rules. It is therefore especially the middle level of control and implementation bodies that

25. This generalizes and respecifies the concept of the political constitution as developed by Niklas Luhmann, Verfassung als evolutionäre Errungenschaft, 9 RECHTSHISTORISCHES JOURNAL 176, 204-08 (1990).

26. For more about the autoconstitutionalization of private regimes, see Andreas Fischer-Lescano \& Gunther Teubner, Regime-Collisions: The Vain Search for Legal Unity in the Fragmentation of Global Law, 25 MICH. J. INT'L L. 999, 1014-17 (2004); Harm Schepel, Constituting Private Governance Regimes: Standards Bodies in American Law, in TRANSNATIONAL GOVERNANCE AND CONSTITUTIONALISM, supra note 11 , at 163, 165-70. Double reflexivity is also used as a criterion for the constitutional elements in global administrative law. See Ming-Sung Kuo, Between Fragmentation and Unity: The Uneasy Relationship Between Global Administrative Law and Global Constitutionalism, 10 SAN DIEGo INT'L L.J. 439, 454, 465 (2009). 
mediate between abstract principles and concrete corporate decisions. ${ }^{27}$ Thus, private codes not only generate autonomous law as private ordering; but also, at the same time, they constitute their own constitutional foundations without being dependent on public codesthey literally generate constitutions without the state.

Accordingly, Olaf Dilling, Martin Herberg, and Gerd Winter noted the findings of an empirical research project about transnational corporate codes and headed his comments with a certain degree of astonishment:

In some respects, the quasi-legal orders of world society themselves show constitutional characteristics. In addition to different social and ecological standards and to existing mechanisms of control and implementation, superior norms develop that define where the decision making power should be located, how violations should be handled, and how third parties should be included. By analogy to state constitutions, private regulations embody mechanisms of self-restraint to reduce intrusions on other actors and other domains. Is world society thus about to develop functional equivalents to the classical constitutional state, and will the latter gradually become marginal? ${ }^{28}$

The answer is: indeed, societal constitutions are functional equivalents to state constitutions, and transnational corporate codes indeed have constitutional characteristics. But this does not mean that the constitutional state becomes marginal. Rather, it remains part and parcel of a constitutional pluralism in global society in which corporate constitutionalism plays a legitimate role.

\section{B. Binary Metacoding of the Corporate Constitution}

To grasp the internal structure of such a double reflexivity, at this point, one has to go beyond the introduced conception of constitutions as the structural couplings of law and social system, since the endpoint of the constitutionalization of a corporation is reached when a specific binary metacoding develops and when intracompany processes take the

27. Herberg, supra note 24, at 410.

28. Olaf Dilling, Martin Herberg \& Gerd Winter, Introduction: Private Accountability in a Globalising World, in RESPONSIBLE BUSINESS: SELF-GovernANCE AND LAW IN Transnational Economic Transactions, supra note 8, at 1, 8. 
latter explicitly as a point of orientation. The metacoding oscillates between the values "code-compatible" and "code-adverse," both with regard to the corporate constitution. ${ }^{29} \mathrm{~A}$ metacoding exists in this case, because such a constitutional code subjects the already binary coding of intracompany legal norms to an additional examination, namely whether they conform to the requirements of corporate constitutional law. Here, the hierarchy between simple and constitutional law emerges, which is typical for all constitutions-political state constitutions, societal constitutions, or the constitutions of formal organizations. The legal code (legal/illegal) is subordinated to the constitutional code (constitutional/unconstitutional). However, there is something peculiar to the constitutional metacoding. It is not only hierarchically superior to the legal code but also at the same time to the economic code. It therefore subjects to reflection all economically binarycoded operations of the corporation, whether they comply with the principles of the public responsibility of the corporation or not.

The constitutional metacoding is therefore a hybrid. It serves as a fictional unity for two different constitutional reviews within the corporation. It is, on the one hand, placed hierarchically above the legal and, on the other hand, above the economic binary code. Therefore, it assumes a different meaning depending on whether it reviews the economic or the legal code. In economic contexts, it reflects the social responsibility of the company and seeks to identify strategies for environmentally friendly economic activities. In the context of corporate law, it introduces the distinction between simple and constitutional law and reviews simple legal acts for their compliance with the values and principles established in the corporate constitution.

Although the constitutional code presents itself ostensibly as a unit, it is, depending on its context, either economic metacode or legal metacode. This has to do with the fact that corporate constitutions, as the structural coupling of two mutually closed social systems, economy and law within the corporation, do not constitute a unitary social system. Both systems do not merge in the corporate constitution; rather, they remain operationally closed. This is the reason why the difference between code-compatible and code-adverse is only a common umbrella formula for respectively different meaning-producing operations, which assume different meanings depending on the context. The metacoding

29. At this point, terminological confusion is almost inevitable since "code" can take on two different meanings. One stems from codex and codification and produces "corporate codes of conduct," "behavioral codices," and so on. The other is binary coding, that is, the orientation of an action system toward a "distinction directrice," such as lawful/unlawful, moral/immoral, and so on. Both meanings meet in corporate codes; analytically, however, they must be kept apart. 
triggers the reentry of fundamental principles of economic organization into the law as constitutional principle and, vice versa, the reentry of law in the corporate organization. ${ }^{30}$

\section{CONSTitutional Institutions: PRIVATE AND PUBlic Codes in AN ULTRACYCLE}

Even if in this way constitutional functions and structures can be identified, it remains difficult to capture the institutional structure of corporate codes in more theoretical detail. Some authors describe corporate codes as the "new sovereignty" of TNCs and thereby stress their unrestrained self-regulation. ${ }^{31}$ However, this does not do justice to the peculiar linkage of the private codes with the public codes of the state world and their numerous normative dependencies on the environment, because the currently relevant corporate codes emerge from the interactions of three groups of actors-supranational institutions, civil society groups, and TNCs-whose mutual relations remain unclear. ${ }^{32}$

\section{A. The Inversion of Nation-State Hierarchies}

Other authors try to model these relations as "governance triangles." 33 This is, however, similarly inadequate for grasping the social embedding of the codes. It mistakenly suggests that a transnational corporatism emerges, equivalent to the state-organized, neocorporatist triangle of the European welfare states. In this way, corporate codes appear as a global variant of national corporate constitutions-state share, codetermination in the board of directors, involvement of employees in management decisions, and free collective

30. The connection of structural coupling and hybrid metacoding is even more clearly discernible in the fully developed political constitutions of modernity. Also there, the different constitutional/unconstitutional binary metacode of two systems-law and politics, both binary coded themselves-works without amalgamating the constitution into a single system through the metacode. Such a metacoding appears (implicitly or explicitly) also in societal constitutionalism (i.e., in the structural coupling of law with different social systems).

31. This characterization is then also used to argue that "self-policing" cannot work. See, e.g., Mahmood Monshipouri et al., Multinational Corporations and the Ethics of Global Responsibility: Problems and Possibilities, 25 HUM. RTS. Q. 965, 989 (2003).

32. Their trilateral character is stressed by Adelle Blackett, Codes of Corporate Conduct and the Labour Regulatory State in Developing Countries, in HARD CHOICES, SOFT LaW: Voluntary STANDaRds IN Global Trade, ENVIRONMENT aNd Social GOVERNANCE 121, 129 (John J. Kirton \& Michael J. Trebilcock eds., 2004).

33. See generally Abbott \& Snidal, supra note 5, at 512-19. 
bargaining-which have emerged out of the organized cooperation of the state, capital, and labor. ${ }^{34}$ In comparison to the nation-states, however, one is confronted here with a totally different constellation in the relationship between these three social forces.

Also, the model of "multilevel governance" is hardly appropriate for capturing the peculiar interplay of the two transnational types of code. ${ }^{35}$ In the nation-state, corporate constitutions could certainly be conceived as a multilevel arrangement of constitutional norms and legal and judicial rules, on the one hand, and intraorganizational private ordering, on the other. It offers also an adequate model for the new forms of governance that emerge in the European Union and the WTO. But its transfer to global corporate constitutions is mistaken. Apart from the formal similarity, namely that legal rules are enacted at different public and private levels, transnational corporate codes do not show features typical for multilevel governance. Neither is precedence given to public codes over private ones in a hierarchy of norms, nor do quasi-federal relations exist here. The different conditions of the transnational, as well as the results of the first wave of constitutionalization, especially the high autonomy of TNCs, have fundamentally changed the relationship between public and private collective actors compared to the corporate constitutions of the nationstate. In the drastic words of an observer, "[c]ontract replaces law; networks of relationships replace a political community; interest replaces territory; the regulated becomes the regulator." 36

As is well known, in the corporate constitutions of European nationstates, the linkage between public and private norms took place in hierarchical formations. The corporate constitution was based on a clear primacy of the state in the form of constitutional, statutory, and judicial norms. Statutory law organized neocorporatist forms of cooperation between capital, labor, and the state via rules of codetermination in the board of directors, decision-making competences of the works committee, and the norms of the wage system. The state private and company law stipulated liability rules and predetermined the orientation of the corporate interest toward different stakeholder interests and the common good. The private ordering of corporations

34. For this parallel, see Tonia Novitz \& Phil Syrpis, Assessing Legitimate Structures for the Making of Transnational Labour Law: The Durability of Corporatism, 35 INDUS. L.J. 367, 393-94 (2006).

35. See Sol Picciotto, Constitutionalizing Multilevel Governance?, 6 INT'L J. Const. L. 457, 461-63 (2008). See generally Ian Bache \& Matthew Flinders, Themes and Issues in Multi-level Governance, in MULTI-LEVEL GovernaNCE 1, 1 (Ian Bache \& Matthew Flinders eds., 2004).

36. Larry Catá Backer, Multinational Corporations as Objects and Sources of Transnational Regulation, 14 ILSA J. INTL \& COMP. L. 499, 523 (2008). 
remained clearly subordinate to state law; it remained limited to those spaces of autonomy state law had left.

This hierarchy of norms can be captured in the conceptual pair of hard law and soft law. ${ }^{37}$ The state enacts hard law in company law, in the law of codetermination, and in regulation law in the form of binding and sanction-reinforced norms. In contrast, intracorporate norms are only a kind of soft law. As a manifestation of private autonomy, they are not recognized as genuine legal norms, because their obligatory nature and enforcement depend on state recognition and because they are subject to the review of state courts, whose results often repeal and change them.

In comparison to this traditional hierarchy, one can detect significant changes in the transnational codes that do not match the standard categories.

From the vantage point of classical legal concepts-for instance, if one conceives law as the sanctioned order of state bodies-the changes in how law is, what law is, can hardly be grasped. The legal concepts of jurisprudence, which are geared toward an either/or of validity, are not suited for uncovering the sublime changes in the way law fulfills its functions and is experienced as meaningful. ${ }^{38}$

In the interplay of the two corporate codes, a downright inversion of the hierarchy between state law and private ordering can be observed. A dramatic reversal takes place especially in the hard or soft law quality of the public and private corporate codes. Now, it is the state norms that feature the quality of soft law, while the mere private ordering of TNCs emerges as a new form of hard law.

The norms under international public law, which, for instance, the United Nations enacted in the Code of Conduct on Transnational Corporations, are not comparable with the binding norms passed for corporate constitutions by parliaments and constitutional courts of the nation-states. Although it was initially planned in the 2003 U.N. Draft Norms on the Responsibilities of Transnational Corporations, that a supranational regulatory body should directly regulate the conduct of TNCs with the help of sanction-reinforced norms binding under

37. On the relationship of both types of rules, see Gregory C. Shaffer \& Mark A. Pollack, Hard us. Soft Law: Alternatives, Complements, and Antagonists in International Governance, 94 MINN. L. REV. 706, 721-29 (2010).

38. NIKLAS LUHMANN, RECHTSSOZIOLOGIE 341 (3d ed. 1987) (author's translation). 
international law, ${ }^{39}$ the massive resistance of influential nation-states and the corporate lobby marked a turning point. The final version contained merely soft law: nonbinding recommendations the implementation of which cannot be enforced by legal sanctions. ${ }^{40}$

On the other hand, intracorporate codes are not merely nonstate private ordering, but in fact, they are the governing law of the land with a high degree of binding force and effective sanctions. Private law doctrine still vehemently contests its genuine legal character, since it insists on the state deduction of normative validity claims and does not recognize private ordering as law. ${ }^{41}$ It is only gradually that economically and sociologically inspired concepts of law emerge, which assign legal character to the normative orders of private transnational actors-under particular circumstances. ${ }^{42}$ Intracompany codes are directly binding for the people involved, and they are equipped with effective sanctions that are executed by newly created compliance departments. ${ }^{43}$

In this way, intracorporate organizational law seals itself off from state law. In direct opposition to the usual norm-hierarchical relationship between state and private law, public codes do not work as the constitutional basis for the authorization of the private codes. They produce their own validity from the linkage of primary and secondary norms in the realm of private ordering. They constitute a closed nonstate system of legal validity, which is itself structured hierarchically. As already mentioned above, the top level encompasses the general principles of the corporate constitution, the middle level

39. U.N. Econ. \& Soc. Council, Comm'n on Human Rts., Sub-Comm'n on the Promotion \& Prot. of Human Rights, Economic, Social and Cultural Rights: Draft Norms on the Responsibilities of Transnational Corporations and Other Business Enterprises with Regard to Human Rights, U.N. Doc. E/CN.4/Sub.2/2003/12 (May 30, 2003).

40. See Larry Catá Backer, Multinational Corporations, Transnational Law: The United Nations' Norms on the Responsibilities of Transnational Corporations as a Harbinger of Corporate Responsibility in International Law, 37 COLUM. HUM. RTS. L. REV. 287, 323-28 (2006).

41. The traditional doctrine of private ordering is astutely criticized by Johannes Köndgen, Privatisierung des Rechts: Private Governance zwischen Deregulierung und Rekonstitutionalisierung, 206 ARCHIV FÜR DIE CIVILISTISCHE PRAXIS 477, 516-18 (2006).

42. See id. at 518-21; Gralf-PETER CALLIESS, GRENZÜBERSCHREITENDE VERBRAUCHERVERTRÄGE: RECHTSSICHERHEIT UND GERECHTIGKEIT AUF DEM ELEKTRONISCHEN WELTMARKTPLATZ 182-244 (2006); Erich Schanze, International Standards: Functions and Links to Law, in LAW AND LEGALIZATION IN TRANSNATIONAL RELATIONS 166, 176-77 (Christian Brütsch \& Dirk Lehmkuhl eds., 2007); Gunther Teubner, Global Bukowina: Legal Pluralism in the World Society, in GLOBAL LAW WithouT A STATE 3, 11-15 (Gunther Teubner ed., 1997). For a lucid analysis of the legal character of private ordering, see John Linarelli, Analytical Jurisprudence and the Concept of Commercial Law, 114 PENN ST. L. REV. 119, 195-211 (2009).

43. See HERBERG, supra note 8, at 48-77. 
regulates enforcement and monitoring, and the lowest level includes concrete rules of conduct. They thus generate their authorizing foundation themselves through their own constitutive rules. Intracompany rules, which regulate conduct according to the legal code, are reviewed according to the constitutional code.

\section{B. Hypercycle and Ultracycle}

Inversion of hierarchy still does not go far enough. While there is a clear factual and normative primacy of the private over the public codes, the primacy is of no hierarchical nature. Rather, what is more appropriate is the exclusion of the public by the private. State norms are not subordinated to private norms; rather, they are banished from the interior of norm setting into the corporate environment. With this, the notion of a unitary legal space of state and private rules becomes obsolete. Instead, two independent legal spaces develop: an autonomous, privately ordered, coercive inner law of corporations, and a stateregulated ensemble of normative recommendations of conduct.

While it seems obvious that these two spaces form two mutually closed legal spaces, it is not easy to determine what constitutes their closure. In any case, it is not the operative closure of social systems in the strict sense that separates them. Their closure is not based on the difference between their operations, as the same type of operations (legal acts) process both code orders. Rather, it is a mutual structural closure that arises from two differences. One is the strict limitation of their space of validity: private codes claim validity for the members of the TNCs, while public codes claim validity for the contracting states. The other is their different quality-one as binding norm and the other as mere normative recommendation. In terms of systems theory, the inner differentiation of the global legal system arises not through the emergence of a new kind of legal operations, which would trigger an operative closure between the newly created subsystems. Rather, the validity symbol is transferred in such a way that it creates boundaries between different legal orders. ${ }^{44}$ It brings about the structural closure

44. Luhmann only develops the temporal dimension of the validity symbol. See Niklas Luhmann, Die Geltung des Rechts, 22 RECHTSTHEORIE 273, 277 (1991). On this basis, the validity symbol is indeed ill-suited to highlight the particularities of transnational law, especially of functional regimes. See Marc Amstutz \& Vagios Karavas, Weltrecht: Ein Derridasches Monster, in SozIOLOGISCHE JURISPRUDENZ: FESTSCHRIFT FÜR GUNTHER TEUBNER ZUM 65. GEBURTSTAG, supra note 7 , at $645,650-53$. If one stresses in contrast the spatial, personal, social, substantial, and especially functional dimensions of the validity of law, then transnational regimes can be clearly distinguished from national legal systems. 
by defining boundaries between different spaces of validity. Traditionally, the validity spaces are defined by territorial boundaries as in nation-states, regions, or cities. In the transnational context, they are of an issue-specific, functional, or jurisdictional kind. Hence, one has to distinguish clearly between different forms of closure, operative and structural, which consequently also result in the different ways that legal orders open up to each other. ${ }^{45}$ In this way, the private and public codes constitute two mutually closed legal orders, between which no transfer of validity takes place, but which influence each other in different ways.

How are the boundaries between private and public codes defined? It would be a further misunderstanding to determine them as boundaries between formal organizations-TNCs, on the one side, and international organizations, on the other. Rather, in both legal spaces, extensive normative networks have developed between different organizations, which then facilitate the understanding of the entire configuration as the relationship between two different, mutually closed normative networks. On the one hand, private codes have already transcended the confines of individual companies. They have extended their validity to corporate conglomerates that transcend national boundaries and encompass in some cases thousands of individual companies. Under pressure from the public and civil society organizations, their scope was even extended beyond the boundaries of corporate groups. With contract regulations, powerful groups are able to bind their suppliers and their distribution chains to their corporate codes and use the contractual mechanism also to introduce effective monitoring and sanctioning systems. ${ }^{46}$ On the other hand, interlinks in the codes of the state world can be found. Here, manifold connections between the corporate codes of the ILO, the OECD, the United Nations Organizations, and the European Union have emerged. ${ }^{47}$

The interrelation of these two closed code-networks certainly does not match the traditional relationship between private and public corporate constitutional norms. Often, it is therefore attempted to conceive the relationship itself as a single large network or even a network of networks, as a metanetwork between state and private

45. See generally Gunther Teubner, "L'ouvert s'appuye sur le fermé": Offene Fragen zur Offenheit geschlossener Systeme, 31 SOZIALFORSCHUNG 287 (1991).

46. See Backer, supra note 36, at 508-17 (illustrating some of the characteristics of selfreferencing regulatory committees in his instructive case study on Gap Inc.).

47. See Murphy, supra note 4, at 424-32 (detailing the relationship between governments and multinational corporations as governments push for adoption of corporate codes). 
actors. ${ }^{48}$ This is not necessarily mistaken, but relevant differences disappear. The relation can be captured in more detail in the difference between "hypercycle" and "ultracycle." 49 A hypercycle emerges when communicative operations within a closed network form cycles that are interlinked in a circular way. In contrast, an ultracycle emerges when a cycle of mutual perturbations is developed between closed networks. Within private corporate codes, interlinkages are of a hypercyclical nature; between the cyclical legal operations, which connect to each other within different formal organizations (i.e., TNCs, their suppliers, and their sales organizations), interorganizational direct connections are developed. The validity symbols of private ordering are directly transferred via intraorganizational law and interorganizational contracts. Within this network of private legal operations, the private norms have a direct binding effect on participants and in instances of norm infringements, sanctions are ordered. In this way, a closed scope of private ordering emerges through the hypercyclical linkage of TNCs and other commercial enterprises.

In an entirely different way, these mutually interlinked private codes are connected to public codes. For this kind of connection, unlike the model of the hypercycle, the ultracycle model is appropriate. Although public codes define certain politically desired obligations and establish the boundary between permitted and banned activities, they are only informal recommendations and mere appeals for certain conduct. They are also valid law, yet in a paradoxical form; they are law in force but without legal sanctions. ${ }^{50}$ This means that private codes, which present themselves as self-referentially closed validity circles, are not only entirely independent from public codes when it comes to their validity, but also that public codes cannot even connect normatively to private standardizations. They do not participate in the normative unity of the intracorporate codes. Only from the outside, they can appeal, suggest, motivate, urge, or even compel, but they cannot command or suspend validity. They are only external irritations for the innervalidity cycle of private codes. The codes of the United Nations, the ILO, the OECD, and the European Union are mere constitutional impulses,

48. See Abbott \& Snidal, supra note 5, at 525-26.

49. For the differences between both, see generally Gunther Teubner, Idiosyncratic Production Regimes: Co-evolution of Economic and Legal Institutions in the Varieties of Capitalism, in The Evolution of Cultural EnTtTies: Proceedings of the British ACADEMY 161 (John Ziman ed., 2002); Gunther Teubner, Hypercycle in Law and Organization: The Relationship Between Self-Observation, Self-Constitution and Autopoiesis, in EUROPEAN YEARBOOK IN THE SOCIOLOGY OF LAW 43 (Alberto Febbrajo ed., 1988).

50. The paradoxical nature of soft law as effective formal law is also stressed by Orly Lobel, The Renew Deal: The Fall of Regulation and the Rise of Governance in Contemporary Legal Thought, 89 MINN. L. REV. 342, 388-89 (2004). 
which-certainly with great influence-international organizations send toward TNCs. Whether they indeed coagulate there into binding constitutional norms is not decided by the institutions of the state world but in the inner processes of private organizations.

\section{Learning Pressures: Internal Self-limitations Due to External Constraints}

If under certain circumstances, interrelations between the codes emerge, then an ultracycle arises-a perturbation cycle between the public and private codes. In the usual descriptions of how private and public soft law regimes are interrelated, the fundamental difference, which exists between the hypercycle of private codes and the ultracycle of public and private codes, is concealed. This should, however, not tempt one to dismiss ultracycles as mere political window dressing or as mere white noise of the state world, unable to affect the intracompany codices at all. Former U.N. Assistant Secretary-General John Gerard Ruggie emphasizes this fact especially with regard to the United Nations Global Compact:

Activist groups and some mainstream NGO's fear that because [the Compact] is not a code of conduct, with explicit performance standards and compliance monitoring, the Compact gives companies a free ride. But ... the Compact is a mechanism intended to engage companies in the promotion of UN goals, not to regulate them. Regulation is a perfectly valid objective, but it is not the only one that counts. ${ }^{51}$

But what does count?

What matters are learning pressures (i.e., internal changes induced by external constraints). Both elements have to be present to enable public and private codes to act in combination: an internal change of cognitive and normative structures and external pressure directed toward it. Otherwise ultracyclical linkages do not emerge, and public codes remain external impulses with no effects. Here, the abovementioned special quality of mutual closure becomes apparent, making possible a special quality of mutual opening. "L'ouvert s'appuye sur le fermé" (openness is based on closure). A transfer of validity between

51. John Gerard Ruggie, Taking Embedded Liberalism Global: The Corporate Connection, in Taming Globalization: Frontiers of Governance 93, 126 n.56 (David Held \& Mathias Koenig-Archibugi eds., 2003). 
both is out of the question; instead, learning pressures-other mechanisms of mutual opening -are developed.

At this point, one of the most significant changes in the legal structure that occurs in the transition to world society becomes visible. Niklas Luhmann described this change in the following way:

[A]t the level of the consolidating world society, norms (in the form of values, regulations, purposes) do not anymore steer the pre-selection of the cognitive, rather vice versa the problem of adaptation through learning gains structural primacy and the structural conditions for the capability of all subsystems to learn have to be supported. ${ }^{52}$

This means that two code orders do not simply communicate via the medium of law. The validity of normative expectations is not transferred from one code to another via legal operations. Instead, learning processes of intracompany legal codes are triggered, often even compelled, by nonlegal media-by expertise, political and societal power, and normative persuasion as well as monetary incentives and sanctions. ${ }^{53}$ In this context, cognitive primacy does not mean that corporate codes lose their legal-normative quality and only function as mere cognitive expectation. It is only the relations between the two normative orders that become "denormativized." While the codes themselves remain normative orders, the relations between them switch to cognitive mechanisms.

What does the first element of learning pressures-cognitive learning-consist of? The public codes only provide "templates," behavioral models, principles, best practices, and recommendations for the private codes. The ultracyclical linkage of both codes triggers learning processes, which do not take place as validity transfer of rules within one legal order but run across the boundaries of mutually closed orders. Their particularity is that they do not amalgamate the involved orders into one unitary legal order with common legal operations;

52. NIKLAS LUHMANN, SOZIOLOGISCHE AUFKLÄRUNG 2: AUFSÄTZE ZUR THEORIE DER GESELLSCHAFT 63 (1975) (author's translation).

53. For a forceful account of the involved learning processes illustrated at the example of European initiatives concerning corporate responsibility, see Amstutz \& Karavas, supra note 44, at 655-57. Similarly, for an example of transnational regimes, see generally Poul F. Kjaer, The Metamorphosis of the Functional Synthesis: A Continental European Perspective on Governance, Law and the Political in the Transnational Space, 101 WIS. L. REV. (forthcoming 2010). For the manifold interrelations between hard and soft law, see generally Shaffer \& Pollack, supra note 37. 
rather, they are reconstructed via complex cognitive processes. ${ }^{54}$ It is exactly this separation that makes possible a cognitive surplus value, which is generated when the sparks of perturbations jump across the boundaries between the involved codes. This may even lead to normative innovation. The ultracycle does not end their autonomy; rather, it uses their autonomy to produce new norms, both of hard law in intracompany codes and of soft law in the codes of the state world.

What makes the learning effect special? Corporations can use the public codes to gauge what societal expectations they face without having to follow them completely. In this way, the public codes counterbalance the tunnel vision developed by the private codes and provoke their reorientation toward a transnational public policy. Public codes provide constitutional stimuli for learning similar to the normative demands placed on companies by protest movements and civil society organizations.

What does the second element, pressure, consist of? In this learning process, legal sanctions do not play a prominent role. Rather, extralegal mechanisms are responsible for the effect that corporations take public codes as compulsion for learning and develop their own codes for their particular circumstances. In no way are these extralegal mechanisms inferior to legal sanctions. First and foremost, it is interorganizational power processes - unilateral pressure and political exchange-that force commercial enterprises to develop corporate codes. It cannot be stressed enough that this external pressure is an indispensable condition for corporate codes to exert an effect at all. 'These norms are 'voluntary' in the sense that they are not legally required; however, firms often adhere because of pressure from NGOs, customer requirements, industry association rules, and other forces that render them mandatory in practice." 55

According to current practices, nation-states and the international organizations of the state world have generated the necessary power resources, yet only to a certain extent. The power pressures of protest movements, NGOs, unions, nonprofit organizations, and public opinion have proven to be crucial. Economic sanctions often tip the scales. The sensitivity of consumers, on whose purchase behavior corporations are dependent, and of certain groups of investors, who exert economic pressure on the commercial enterprises, is decisive. ${ }^{56}$ It remains to be

54. See Murphy, supra note 4 , at $422-24$.

55. Abbott \& Snidal, supra note 5, at 506 n.25.

56. For a detailed analysis of the connection between external pressure and intracorporate structure, see generally Jennifer Howard-Grenville et al., Constructing the License to Operate: Internal Factors and Their Influence on Corporate Environmental Decisions, 30 LAW \& POL'Y 73 (2008). 
seen whether the state world will take a leading role in exerting stronger external pressures on corporations after the financial crisis. In this context, the latest news tends to feed skepticism. In any case, although they would change the balance between internal and external regulation, they would not eliminate the difference between hypercycle and ultracycle.

Behind the metaphor of "voluntary codes," therefore, lies anything but voluntariness. TNCs enact their codes neither on the basis of their understanding of common good requirements nor due to motives of corporate ethics. They comply only "voluntarily," when massive learning pressures on them are exerted from the outside. The learning process does not proceed within the legal system from code to code via validity transfer of rules, but on a long and winding detour through other social systems and other media of communication. It is not sufficient to describe this as if legal sanctions are simply replaced by social sanctions. This would conceal the drastic effects such circuitous learning pressures have. In the described ultracyclical "translation processes," system boundaries are in fact transcended; a perturbation cycle emerges between legal acts, pressures of political and societal power, cognitive operations of epistemic communities, and normative persuasion and economic sanctions, which then go back to legal acts in the other code. The original content of the public recommendations is dramatically changed when they undergo a complicated translation process into different worlds of meaning. When the soft law of the public codes is "translated" into the language of expert knowledge, this creates special effects, which develop models and organize monitoring. Different outcomes occur when soft law is translated into the interorganizational power of political negotiations between international organizations, NGOs, and TNCs, and still further different outcomes again occur when it is reconstructed in the reputation mechanisms of the public or in monetary incentives and sanctions. Other changes finally occur when soft law is "retranslated" into the legal parlance of the hard law of intracompany codes. These rather indirect connections between both codes highlight that the autoconstitutionalization of corporations comes about neither due to intrinsic motives of voluntariness, nor due to the sanctioning mechanisms of state law, but due to a circuitous translation process in which different learning pressures come to bear. 